\title{
Assessment of Blood Inflammatory Parameters in Elderly Patients with Peripheral Vertigo
}

\section{Periferik Vertigolu Yaşı Hastalarda Kan Enflamatuar Parametrelerinin Değerlendirilmesi}

\author{
๑Turgut Dolanbay', @Levent Şahin'1, @Hüseyin Fatih Gül'2, @Gönül Şeyda Seydal3, @Murat Aras' \\ 'Kafkas University, Department of Emergency Medicine, Kars, Turkey \\ ${ }^{2}$ Kafkas University, Department of Biochemistry, Kars, Turkey \\ ${ }^{2}$ Niğde Ömer Halisdemir University, Zübeyde Hanım Vocational School of Health Services, Department of Biochemistry, Niğde, Turkey
}

\begin{abstract}
Aim: The aim of this study is to evaluate the relationship between infection-induced Peripheral Vertigo and inflammatory parameters levels, white blood cell, neutrophil to lymphocyte ratio, platelet to lymphocyte ratio and $\mathrm{C}$-reactive protein in elderly patients.

Material and Method: In our study, 122 patients with peripheral vertigo complaints were retrospectively evaluated. Their gender, age, the type of admission, emergency room discharge and hospitalization, hospital admission time, complaints, and physical examination findings rates were examined.
\end{abstract}

Results: The mean age was 73.4 years.. 115 patients (94.3\%) were discharged after follow-up in the emergency department, while 7 patients $(5.7 \%)$ were hospitalized. Complaints were $75.4 \%$ dizziness, $18 \%$ nausea-vomiting and $6.4 \%$ headache, respectively. There was no statistically significant difference in neutrophils, lymphocytes, platelets, neutrophil to lymphocyte ratio and platelet to lymphocyte ratio values.

Conclusion: In our study, white blood cell and C-reactive protein values were found to be higher than the reference values in patients.. The results of our study showed that it can be used actively in the diagnosis of inflammatory causes in the pathogenesis of elderly patients with peripheral vertigo.

Keywords: Peripheral vertigo, inflammatory markers, emergency room, elderly

\section{Öz}

Amaç: Bu çalışmanın amacı, yaşlı hastalarda enfeksiyona bağı periferik vertigo ile inflamatuar parametreler, beyaz kan hücresi, nötrofil lenfosit oranı, platelet lenfosit oranı ve C-reactive protein arasındaki ilişkiyi değerlendirmektir.

Gereç ve Yöntem: Çalışmamızda periferik vertigo şikayeti olan 122 hasta geriye dönük olarak değerlendirildi. Cinsiyetleri, yaşları, başvuru şekilleri, acil servisten taburculuk ve yatışları, hastaneye başvuru süreleri, şikayetleri ve fizik muayene bulgu oranları incelendi.

Bulgular: Ortalama yaş 73,4 yıldı. 115 hasta $(\% 94,3)$ acil serviste izlem sonrası taburcu edilirken, 7 hasta $(\% 5,7)$ hastaneye yatıııldı. Şikayetler sırasıyla \%75,4 baş dönmesi, \%18 bulantıkusma ve \%6,4 baş ağrısı idi. platelet, nötrofil, lenfosit, nötrofil lenfosit oranı ve platelet lenfosit oranı değerlerinde istatistiksel olarak anlamlı fark yoktu.

Sonuç: Çalışmamızda hastalarda beyaz kan hücresi ve C-reactive protein değerleri referans değerlerine göre daha yüksek bulundu. Çalışmamızın sonuçları, periferik vertigolu yaşı hastaların patogenezinde inflamatuar nedenlerin, tanıda aktif olarak kullanılabileceğini göstermiştir.

Anahtar Kelimeler: Periferik vertigo, inflamatuar belirteçler, acil servis, yaşlı 


\section{INTRODUCTION}

Vertigo is defined as the perception of a rotational or translational movement of the patient himself or surrounding objects. It is one of the most common clinical symptoms and reasons for admission to the emergency department and outpatient clinics. ${ }^{[1,2]}$ It affects approximately $20-30 \%$ of the world population and also decreases the quality of life of patients. ${ }^{[3]}$ Peripheral vertigo (PV) is a type of vertigo that usually occurs due to infections of the inner ear such as otitis and labyrinthitis. The most common causes of PV are benign paroxysmal positional vertigo (BPPV), ménière's disease, labyrinthitis, vestibular neuritis, and perilymph fistula. ${ }^{[4,5]}$ Infection, inflammatory and immunological factors are thought to play a significant role in the etiology of PV. But the exact cause of the condition is unknown yet. ${ }^{[6]}$

Complete blood count (CBC) parameters such as neutrophil, lymphocyte, and platelet provide useful information about infection and general inflammatory conditions. In recent years, the neutrophil to lymphocyte ratio (NLR) and platelet to lymphocyte ratio (PLR) have been proposed as novel parameters that demonstrate the systemic inflammatory response. NLR and PLR can be easily calculated from the CBC. Some studies have shown that NLR and PLR ratios are associated with the diagnosis and prognosis of several diseases such as vestibular neuritis, sudden sensorineural hearing loss ( $\mathrm{SSHL})$, and peripheral facial palsy C-reactive protein (CRP), an acute-phase protein, is a useful marker of pathological processes including infection, tissue damage, and chronic inflammatory disease. ${ }^{[7,9]}$ The level of CRP in the blood increase when there is a condition causing inflammation.

According to the literature survey, the association between NLR, PLR, CRP, and PV has not been previously studied. These inflammatory markers have been evaluated separately in many studies. However, this is the first study in which they are evaluated together. The aim of this study is to evaluate the relationship between infection-induced PV and inflammatory parameters levels, white blood cell (WBC), NLR, PLR and CRP in elderly patients.

\section{MATERIAL AND METHOD}

\section{Study Design}

This retrospective study was conducted on 122 patients over the age of 65 who presented to the emergency department, Kafkas University Health Research and Application Center with complaints of peripheral dizziness and infection between 01.10.2018-01.10.2019. The study was carried out with the permission of Kafkas University Faculty of Medicine Ethics Committee (Date: 30.10.2019, Decision No: 11) and was conducted according to the principles of Declaration of Helsinki. Informed consent statements were obtained from all patients. The medical files were reviewed retrospectively and the following data were recorded; demographic properties (age, gender), the type of admission, emergency room discharge and hospitalization, hospital admission time, complaints, and physical examination findings.

Inclusion criteria were complaints of peripheral vertigo due to infection, no history of trauma, no chronic inflammation and infectious diseases, no hematological diseases, no chronic liver disease, no chronic renal failure, no cardiovascular disease, no malignancy, and patients aged 65 years or older. - Patients with a history of trauma, chronic inflammation and infection, hematological diseases, chronic liver disease, chronic renal failure, cardiovascular diseases, malignancy and those under 65 years of age were excluded from the study.

WBC, neutrophils (NEU), lymphocytes (LYM), platelets(PLT), and CRP values at the time of admission to the emergency department were analyzed using hospital registries. An automated blood cell counter was used for $C B C$ measurements using ABX Pentra DX 120 (Horiba, HORIBA ABX SAS, Japan). The NLR values were calculated by dividing the neutrophil count by the lymphocyte count and PLR values were calculated by dividing the platelet count by the lymphocyte count. CRP measurements were done using an automated analyzer (cobas 6000 Series system, c501 module, Roche, Germany) using nephelometric measurement. Results were considered based on laboratory's reference ranges.

\section{Statistical Analysis}

Statistical analysis was performed with the SPSS 22 software package. Pearson's chi-square test was used for categorical data analysis. The data were expressed as numbers and percentages. Mean, standard deviation, minimum-maximum values, frequency were included in the descriptive statistics of the data. A $p$ value of $p<0.05$. Was accepted as statistically significant.

\section{RESULTS}

A total of 122 patients were enrolled in the current study. $61(50 \%)$ of them, were males, 61 (50\%) were females. The mean age was 73.4 years with a minimum age of 65 years and a maximum age of 88 years. The demographic characteristics and laboratory test results of patients are presented in Table 1.

\begin{tabular}{|c|c|c|c|c|c|}
\hline Variable & Mean & $\begin{array}{l}\text { Standard } \\
\text { deviation }\end{array}$ & $\max$ & $\min$ & Ref \\
\hline Age (years) & 73.4 & 7.62 & 88 & 65 & \\
\hline $\operatorname{WBC}\left(10^{9} / \mathrm{L}\right)$ & 10.91 & 14.80 & 167.8 & 3.4 & $3.7-10.4$ \\
\hline $\operatorname{PLT}\left(10^{3} / \mu \mathrm{L}\right)$ & 243.60 & 68.70 & 416.0 & 52 & $149-371$ \\
\hline $\operatorname{NEU}\left(10^{3} / \mathrm{mm}\right)$ & 5.24 & 2.41 & 13.4 & 2.2 & $1.8-7.8$ \\
\hline $\operatorname{LYM}\left(10^{3} / \mathrm{mm}\right)$ & 2.18 & 0.96 & 5.1 & 0.7 & $0.9-3.7$ \\
\hline CRP (mg/L) & 0.85 & 3.08 & 27.8 & 0.009 & $0-0.5$ \\
\hline NEU/LYM & 2.88 & 2.03 & 12.97 & 0.70 & \\
\hline PLT/LYM & 133.27 & 67.16 & 394.12 & 41.22 & \\
\hline
\end{tabular}


As shown in Table 1, the mean value of WBC, PLT, NEU, LYM, NEU/LMY, PLT/LYM and CRP were 10.91 (3.4-167.8), 243.60 (52- 416.0), 5.24 (2.2-13.4), 2.18 (0.7-5.1), and 0.85 (0.00927.8), respectively. No statistically significant differences were observed in values of PLT, NEU, LYM, NEU/LYM and PLT/LYM. On the other hand, the mean values of WBC and CRP of the patients were significantly higher than the reference range.

The hospitalization rates of the patients are summarized in Table 2. The distribution of genders was similar between females and males. When we evaluated the hospital admission time of all patients, we determined that the most common admission time was between 12:00 a.m and 5:59 p.m. (Table 2).

\begin{tabular}{|c|c|}
\hline & Frequency (\%) \\
\hline \multicolumn{2}{|l|}{ Gender } \\
\hline Female & $61(50 \%)$ \\
\hline Male & $61(50 \%)$ \\
\hline \multicolumn{2}{|c|}{ Hospital admission time (h) } \\
\hline 00:00-05:59 & $7(5.7 \%)$ \\
\hline 06:00-11:59 & $36(29.5 \%)$ \\
\hline 12:00-17:59 & $44(36.1 \%)$ \\
\hline 18:00-23: 59 & $35(28.7 \%)$ \\
\hline
\end{tabular}

On the other hand 115 patients (94.3\%) were discharged after follow-up in the emergency department, while 7 patients $(5.7 \%)$ were admitted hospital. When compared the hospitalization rates of patients with peripheral vertigo according to gender by Pearson's chi-square test, 4 were male and 3 were female, there was no significant difference between males and females $p<0.696$ (Table 3).

\begin{tabular}{lcc}
$\begin{array}{l}\text { Table 3. Gender ratio of hospitalized patients } \\
\text { Hospitalization }\end{array}$ & P value \\
\hline No & $115(94.3 \%)$ & \\
Male & 57 & 0.688 \\
Female & 58 & \\
Yes & $7(5.7 \%)$ & \\
Male & 4 & 0.696 \\
Female & 3 & \\
\hline
\end{tabular}

The most common complaints were $75.4 \%$ dizziness, $18 \%$ were nausea and vomiting and $6.4 \%$ were headache. There were both dizziness and abdominal pain in two patients. There were both headache and syncope in one patient. In the physical examination, horizontal nystagmus was observed $95 \%$ (116) of the patients.

\section{DISCUSSION}

Vertigo is a common symptom worldwide that adversely affects the quality of life and imposes a serious social and economic impact on the health care. ${ }^{[10]}$ In the etiopathogenesis of vertigo, several etiologic factors such as infection, immunologic and inflammatory play a causal role, but the exact causes remain unknown. In recent years, an increasing number of studies have been conducted to demonstrate the relationship between inflammation and vertigo and has been reported that inflammatory diseases could lead to vertigo. ${ }^{[9,11]}$ Inflammation can be measured using a number of biochemical and hematological parameters. Research results indicate that assessment of WBC and its subtypes might have prognostic significance for some diseases related to inflammation. ${ }^{[12]}$ Some changes have been observed in inflammatory markers depend on the underlying pathological conditions. In addition to physical, and neurological examination in the diagnosis and treatment of the disease, various studies have been also conducted on the use of these inflammatory markers. [13,14] Therefore, in the current study, we investigated the relationship between peripheral vertigo and inflammatory parameters. To the best of our knowledge, this is the first study to evaluate together WBC, NLR, PLR, and CRP values in elderly patients with peripheral vertigo.

Higher neutrophil counts were associated with inflammatory conditions and a low lymphocyte count was associated with higher physiologic stress. Under physiological stress conditions, the number of neutrophil count increases, while the lymphocyte count decreases. For this reason, the NLR ratio is considered as a parameter in inflammatory conditions. PLR also provide important information about the inflammatory condition such as NLO. ${ }^{[7,15]}$ Several studies have been shown that the NLR and PLR use as an inflammatory biomarker to determine inflammation in several diseases including tinnitus, acute hearing loss, Bell's palsy and vertigo. $[9,11,15]$

As seen in the literature, research results about parameters of inflammatory in peripheral vertigo remain controversial. Chung et al. ${ }^{[7]}$ investigated the relationship between NLR and PLR values and vestibular neuritis (VN) and found a significantly higher NLR and PLR value in patients with VN. In this regard, they proposed that these rates are simple and reliable parameters for predicting the cause and the severity of VN. Another study revealed that NLR values were significantly higher in patients with VN, while no significant differences were detected in PLR values. They reported that the results show the presence of a correlation between NLR and VN, suggest the presence of an inflammatory process related to VN, and may help the differential diagnosis of patients presenting with vertigo to the emergency department. ${ }^{[16]}$ According to a study conducted by Tekesin and Tunç ${ }^{[11]}$ for evaluating inflammatory biomarker levels in BPPV patients, NLR and PLR values were found higher in BPPV patients. Thus, results demonstrated that inflammation may be connected with the pathogenesis of BPPV. The study of Sahın et al. ${ }^{[15]}$ evaluated that the NLR differences between the differential diagnoses and follow-up of patients with peripheral, BPPV and VN.

They found that NLR levels were significantly higher in patients with BPPV than in those with VN and demonstrated that the NLR could be used in evaluating the differential diagnosis of peripheral vertigo. Similar results were also obtained in 
the study of Ozbay et al. ${ }^{[17]}$ NLR values were significantly higher in patients with peripheral vertigo and a significant relationship between inflammation and peripheral vertigo. In our study, unlike previous studies, we found that PLR and NLR levels were not significantly different for peripheral vertigo caused by infection in elderly patients with peripheral vertigo. Consistent with most previous studies, the study of Temirbekov and Sakalli ${ }^{[18]}$ showed no statistically significant difference in NLR and PLR in patients with peripheral vertigo. In this respect, we think that NLR and PLR ratios can be used in certain vertigo types.

CRP is another one of the markers of inflammation which was widely used for the assessment of inflammation in clinical practice and has been recognized as associated with several inflammatory diseases. In some types of vertigo have been shown an increased value of CRP. ${ }^{[14]}$ Milionis et al. ${ }^{[19]}$ found that CRP increase in patients with vestibular neuritis. However, other studies have not found an increased risk. Akıncı et al. ${ }^{[14]}$ reported that no significant change concerning CRP levels in peripheral vertigo.

The most common symptom in vertigo patients is dizziness. These symptoms are followed by nausea, vomiting and headache. ${ }^{[5,20]}$ The symptom rates of our patients are compatible with the literature, and in our study, dizziness was the most common cause of emergency admissions.

In general, patients with peripheral vertigo can be discharged in emergency departments as soon as symptoms are controlled. Patients with resistant symptoms and signs or with additional chronic diseases can be hospitalized. ${ }^{[21]}$ In our study, we are consistent with the literature, and we think that our hospitalizations were caused by cases of vertigo originating from infection that did not respond to medical treatment applied in the emergency department.

In our study, we found a significantly higher CRP value in patients. However, when we examined the literature, it showed inconsistent infection parameter results. It can be thought that most of the causes of vertigo cannot be attributed to infection. However, we think that CRP is a guide in the diagnosis of patients with peripheral vertigo due to infection.

\section{Limitation}

The most important limitation of this study was that it was planned retrospectively and also there are few sample group in the systemic diseases group categories. There is a need for more comprehensive studies investigating the etiology of peripheral vertigo in the elderly.

\section{CONCLUSION}

In our study, WBC and C-reactive protein values were found to be higher than the reference values in patients. The results of our study showed that it can be used actively in the diagnosis of inflammatory causes in the pathogenesis of elderly patients with peripheral vertigo.

\section{ETHICAL DECLARATIONS}

Ethics Committee Approval: The study was carried out with the permission of Kafkas University Faculty of Medicine Ethics Committee (Date: 30.10.2019, Decision No: 11).

Informed Consent: Because the study was designed retrospectively, no written informed consent form was obtained from patients.

Referee Evaluation Process: Externally peer-reviewed.

Conflict of Interest Statement: The authors have no conflicts of interest to declare.

Financial Disclosure: The authors declared that this study has received no financial support.

Author Contributions: All of the authors declare that they have all participated in the design, execution, and analysis of the paper, and that they have approved the final version.

\section{REFERENCES}

1. Tusa RJ. Bedside assessment of the dizzy patient. Neurol Clin 2005;23:65573.

2. Kablan A, Karaman S, Başol N. Cost of neuroimaging of patients with vertigo in emergency department. J Contemp Med 2019;9:315-20.

3. Strupp $M$, Brandt T. Diagnosis and treatment of vertigo and dizziness. Dtsch Arztebl Int 2008;105:173-80.

4. Labuguen RH. Initial evaluation of vertigo. Am Fam Physician 2006;73:24451.

5. Hanley K, O'Dowd T. Symptoms of vertigo in general practice:a prospective study of diagnosis. Br J Gen Pract 2002;52:809-812.

6. Greco A, Macri GF, Gallo A, et al. Is vestibular neuritis an immune related vestibular neuropathy inducing vertigo? J Immunol Res 2014;2014:8.

7. Chung JH, Lim J, Jeong JH, Kim KR, Park CW, Lee SH. The significance of neutrophil to lymphocyte ratio and platelet to lymphocyte ratio in vestibular neuritis. Laryngoscope 2015;125:257-61.

8. Avcı D. Can mean platelet volume be used as a thrombosis marker in subjective tinnitus? Erciyes Med J 2020;42:157-62.

9. Seo YJ, Jeong JH, Choi JY, Moon IS. Neutrophil-to-lymphocyte ratio and platelet-to-lymphocyte ratio:novel markers for diagnosis and prognosis in patients with idiopathic sudden sensorineural hearing loss. Dis Markers 2014;2014:6

10. Kovacs E, Wang X, Grill E. Economic burden of vertigo:a systematic review. Health Econ Rev 2019;9:37.

11. Tekeşin A, Tunç A. Inflammatory biomarkers in benign paroxysmal positional vertigo: a Turkey case-control study. Ideggyogy Sz 2018;71:4116.

12. Bas FY, Tola EN, Sak S, Cankaya BA. The role of complete blood inflammation markers in the prediction of spontaneous abortion. Pak J Med Sci 2018;34:1381-5.

13. Fattori B, Nacci A, Ghilardi PL, Bruschini L, Matteucci F, Ursino F. Acute peripheral vertigo:involvement of the hemostatic system. Int Tinnitus J. 2003;9:2:124-9.

14. Akinci E, Aygencel G, Keles A, Demircan A, Bildik F. Role of C-reactive protein, D-dimer, and fibrinogen levels in the differential diagnosis of central and peripheral vertigo. Adv Therapy 2007;24:1068-77.

15. Sahın C, Varım C, Uyanık M, Acar B, Acar T, Nalbant A. Use of neutrophils to lymphocytes ratio as an inflammation marker in patients with chronic tonsillitis. Georgian medical news, New York:2016;256-257:52-57.

16. Shushan S, Shemesh S, Ungar OJ, et al. Neutrophil-to-lymphocyte ratio and platelet-to-lymphocyte ratio among patients with vestibular neuritis. ORL 2019;81:304-8. 
17. Ozbay I, Kahraman C, Balikci HH, et al. Neutrophil-to-lymphocyte ratio in patients with peripheral vertigo:a prospective controlled clinical study. Am J Otolaryngol 2014;35:699-702.

18. Temirbekov D, Sakallı E. Effects of peripheral vertigo on inflammatory and immunologic laboratory markers. Ear Nose Throat J 2020;99:470-4.

19. Milionis HJ, Mittari V, Exarchakos G, Kalaitzidis R, Skevas AT, Elisaf MS. Lipoprotein (a) and acute-phase response in patients with vestibular neuronitis. Eur J Clin Invest 2003;33:1045-50.

20. Yardley L. Contribution of symptoms and beliefs to handicap in people with vertigo:a longitudinal study. Br J Clin Psychol 1994;33:101-13.

21. Dağkıran M, Sürmelioğlu Ö, Özlem A. Diagnosis and treatment approach in benign paroxysmal positional vertigo. Archiv Med Rev J 2015;24:55564. 